\author{
Natalia Kiser \\ University of Warsaw \\ n.kiser@uw.edu.pl
}

\title{
Audio description in puppet theatre for children - a case study
}

\section{Introduction}

Audio description (henceforth $\mathrm{AD}$ ) is a fast growing arts and media access service for blind or visually-impaired people (BVI) that prevents them from exclusion from audiovisual-based social and cultural discourses that have dominated today's world [Braun, 2008: 14]. AD offers verbal descriptions of visual objects such as paintings, sculptures, art pieces in museums and art galleries, as well as gives a combination of description, interpretation and translation of essential visual elements in filmed and live performances such as films, TV programmes, opera, dance performances or theatre, that consist of oral commentary inserted in appropriate silence gaps, for example in between the dialogues [Ofcom, 2000].

Since translation of visual images into verbal descriptions is a key element of AD process, audio description is considered to be a field of Translation Studies and a subject of numerous academic essays, doctoral dissertations, publications, international specialized conferences and seminars, and research at both undergraduate and postgraduate level [Szarkowska, 2008: 8].

Thanks to on-going research on $\mathrm{AD}$, development and enhanced introduction in many productions and cultural events, more and more audience with disabilities can enjoy both cinema or television screenings and live venues that otherwise would remain hermetic and inaccessible to them [Díaz Cintas, 2005: 3]. However, few studies have been published about AD in theatre, be it for adults or children, and even less on $\mathrm{AD}$ for children's puppet theatre. Yet it is a vast artistic area where audio 
description should be introduced, as young visually impaired spectators are entitled to be given the same chance of experiencing theatre performances, understand emotions of actors, discover intensions of creators of a play, and get to know the vision of artists to the same extent as their sighted counterparts do.

\section{Theatre accessibility for the blind in Poland}

Today, the map of Polish theatres is densely spotted with venues where performances with AD are provided to their viewers. The 2007 Białostocki Teatr Lalek AD initiative was followed by audio described performances in numerous theatres all over the country. Thanks to the Fundacja Kultury bez Barier (Culture without Barriers Foundation) project "Poza ciszą i ciemnością" (Theatre Beyond Silence and Darkness), co-financed by the Polish Ministry of Culture and National Heritage, 72 performances have been staged with $\mathrm{AD}$ in 19 Polish theatres since 2009.

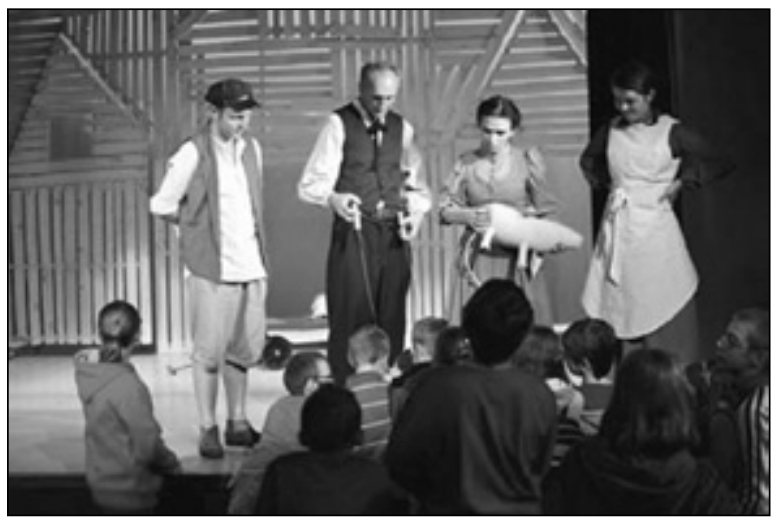

Fig. 1. An after-show touch-tour in Baj Theatre in Warsaw (phot. theatre archive)

Similarly to European standards and practices, Polish theatres also offer their blind and partially-sighted audience some pre- or after-show touch-tours. Apart from discovering sets, props, and costumes, young and adult viewers are given an opportunity to touch and get to know puppets that are used in some puppet performances. 


\section{Audio description in theatre}

In comparison with writing an $\mathrm{AD}$ script for a film, preparing audio description for the theatre performance is a much more complex not to say complicated - task. In theatre, $\mathrm{AD}$ must not only fit into the gaps between actors' dialogues, leave some silent moments in a performance, and avoid presenting characters' motivation and intensions as well as describing commonly known sounds, but also:

\section{[...] good description must allow}

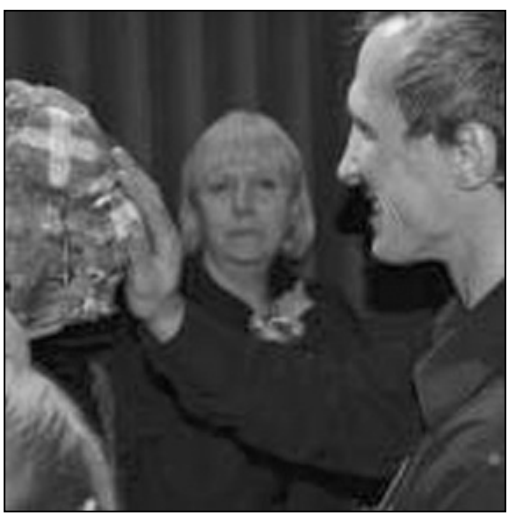

Fig. 2 Discovering puppets in the Baj

Theatre (phot. theatre archive) the viewer to enter into a relation with the object, person or painting being described 'as a whole'. This means integrating the description so that it becomes part of the artistic experience, rather than keeping that experience at arms' length [Holland, 2009: 184].

According to Holland [2007: 175], theatre AD has two levels: literal and imaginative. In other words, the describer's task is to maintain the balance between the literal truth of a described scene and the imaginative truth of its certain elements, i.e. illusion, so that the AD text does not break the suspension of disbelief. As theatre is the kingdom of metaphor and interpretation, these features should be somehow reflected in its AD.

Another important aspect that differentiates theatre AD from other genres is the question of "impartiality" and "objectivity". Even though the describers are constantly being reminded to avoid subjective relations and interpretation in their scripts [ADI, 2005; ITC, 2000; Szymańska, Strzymiński, 2010], practice shows that it is impossible not to interpret scenes and actions, since the entire play is a director's, actors' and whole creative team's interpretation of a text or a subject. According to Szarkowska and Künstler [2012], the describers start AD preparation with watching a recording of a performance, its pictures, props, costumes, etc. Then, if only given an opportunity, they are advised to speak with actors, the stage designer, the music composers and the director of 
the play in order to find out as much as they can about the artistic aspects of the performance [Holland, 2007: 174]. In the end, the ultimate goal of theatre $\mathrm{AD}$ is to transmit a creative team's vision and assumptions of their piece of art. Furthermore, Holland points out [2007: 184] that theatre $\mathrm{AD}$ consists in translating artistic material from one medium to another, and "there is not any direct equivalence between action on stage and the words chosen to describe it". The describers should not tell the visually impaired audience the physical details of something they cannot see, but convey the message that stands behind it. This is why Holland argues that seeing is not a synonym of understanding, and the famous Snyder's notion "say what you see" should be paraphrased into "say what you understand" [Holland, 2007: 185].

Due to the fact that theatre performances are live, and, as a consequence, unpredictable, their AD must not only be read by a voice talent, but also has to be delivered live. A voice talent should be prepared that actors might change the rhythm of scenes, make a mistake, add or forget some text, and then s/he should react flexibly to what is happening on stage, being a simultaneous interpreter rather than just a narrator. Other unexpected situations that change the play into a big extent involve some technical perturbations or a replacement of an actor - an introduction of a new person on stage results in significant changes of the performance.

An additional consideration for the theatre $\mathrm{AD}$ is that described performances are usually dynamic events and are overloaded with dialogues and sound stimuli. Numerous time constraints are among many difficulties that audio describers must face. In most situations voice talents have a fraction of second to deliver the description during a scene. In order not to "violate" the rule of no overlapping between AD and text and/or music, audio introduction (AI), is a commonly used solution. According to ADC [2009: 9], its role is to "prepare the patron by including descriptions that the describer will not have time to give during the performance, e.g. descriptions of the sets, physical characteristics of characters, their roles, costumes, gestures, mannerisms, etc.". These descriptions are read before the show starts, either in front of the public, or by using the microphone and headsets. Very often AI includes some stage and theatrical terminology and jargon so that during the performance itself the action may be described in terms of the story. This reinforces the magic of the "fourth wall" and "suspension of disbelief". 
Last but not least, AD in theatre usually includes "touch-tours" - special visits to the backstage that aim at touching and discovering all the elements, props, costumes, sets, puppets, etc. that will appear or have appeared in the play. Touch-tours are organized either before performances or after them. According to spectators [Calderazzo, 2010: 173], the experience provided by touch-tours facilitates the formation of the so-called "stage-in-the-head" model, where all the auditory information melts with the specific impressions of the stage, giving the image of the action that takes place in front of the audience members.

\section{Audio description in children's theatre}

The World Health Organization (WHO) reports that there are approximately 1.4 million blind children worldwide, of whom $3.8 \%$ are younger than 15 years and approximately three-quarters of the world's blind children live in the poorest regions of Africa and Asia. ${ }^{1}$ Blindness in children is often accompanied by other physical and/or learning difficulties. Due to the congenital, neo-natal or around birth problems, AD may remain inaccessible for some of them. Moreover, blind and visuallyimpaired children are more likely to have delayed language compared to the fully sighted youngsters [Palomo López, 2008a: 114]. Nonetheless, there is strong evidence that music and speech are processed by different centres in the brain, so children with damaged speech centres can still process verse and melody [ITC, 2000: 28]. Furthermore, blind children use alternative ways of communication with their environment via interaction such as pre-linguistic vocalization as well as touch and audition [Muldorf, Urwin, 1983, in: Palomo López, 2008a: 118]. These differences should be taken into account during the preparation of AD script for children's audiovisual programmes and performances.

\section{Guidelines for audio describing children's performances}

Audio description for children, with its own particularities, challenges and difficulties, represents a separate AD genre [Orero, 2011: 169;

1 www.who.int/blindness/causes/priority/en/index3.html. 
Palomo López, 2008b]. For this reason some vital factors should be taken into consideration when writing a script for children's performances.

First and foremost, ITC guidelines [2000: 28] strongly recommend that an $\mathrm{AD}$ script should be suited to the age group for which the play is intended. Judging by the language capacities of their audience, the describers should select appropriate and understandable vocabulary as well as use interesting adjectives, expressive adverbs and suggestive metaphors. AD for children should also include the description of gestures and facial expressions (e.g. correlating raised eyebrow with disapproval) so that young audience members with visual impairments are able to learn the significance of facial movements and their social meanings [Orero, 2011: 173].

Secondly, the describers should bear in mind that $\mathrm{AD}$ is an additional parallel narration that has to be processed, understood and remembered. For this reason, the script writers are encouraged to reach for syntactically simple sentences without complex and specialized vocabulary, whereas the voice talents are advised to deliver the text at a moderate speed.

Furthermore, as children's performances are packed with music, the voice talents should avoid speaking over songs. However, if vital information is to be conveyed, it should be delivered after the first verse during the repetition of instrumental passages in the song [ITC, 2000: 29].

Subsequently, the tone of narration is also of key importance. If suitable, it will enhance children's experience and will help them understand the tone and emotions of the described scene [Künstler, 2014: 148]. Thanks to a smile, joy, surprise, fright, and finally calm in the narrator's voice, the young spectators may have a feeling that $\mathrm{AD}$ is in fact a fairy tale told especially for them.

\section{Specificity of audio description in puppet theatre}

Unlike film and television, theatre has limitations. A room on stage is not a real room, but a piece of painted canvas. A boy is not a real boy, but a little wooden puppet, etc. However, these limitations leave room for the sighted audience to fill in the gaps and pretend that things are real, so the story may happen. Puppets are inanimate objects that, when watched by sighted spectators, are given life, motion and character [Reason, 2008: 337]. 
A famous notion of McPharlin explains the mechanism of suspension of disbelief:

When puppets come alive, one ceases to think of wood and wire; one is absorbed in the action. [...] The audience, accepting the convention of puppets, projects itself into them with the same empathy that it feels to any other actors [McPharlin, 1938: 47].

As a consequence, it is believed that puppet theatre is a particular theatre where young audiences engage with the illusion and experience the suspension of disbelief.

According to the research conducted by Reason [2008], a great majority of sighted viewers immerse into the illusion of life in the puppet, without distinguishing between the puppeteer who manipulates it and the character that the puppet represents. When asked the question "Did you watch the man or did you watch the goose in the performance?", primary-school-aged children responded by drawing pictures from the play. In most cases these were images of real geese rather than puppets of geese manipulated by actors [Reason, 2008: 348]. It shows that the theatre experience depends on the relationship between reality and illusion that is experienced by spectators. Scholars mention two types of experience - the embodied and the referential one [Sauter, 2000, in: Reason, 2008: 342]. The embodied experience relates to the actual appearance of the performance, i.e. to what the audience sees on stage: the precise appearance of props, stage flats, lighting effects, etc., whereas the referential experience is what is represented by the performance or what the audience sees in its imagination [Jurkowski, 1983: 124].

In view of the information presented above, writing $\mathrm{AD}$ for puppet performance is an extremely challenging task in terms of conveying all the visual information presented on stage without breaking the fourth wall and depriving visually impaired audience of referential experience of the theatre.

Visits to children's puppet theatre have revealed another major consideration for $\mathrm{AD}$ in the puppet theatre, namely the fact that the young audience is heterogeneous and includes partially-sighted and congenitally blind children, and those who were once sighted. Practice shows that audience members have different "visual memories", with no, partial or full access to the visual mode of narration. 
No empirical data has been collected to support the mouth-to-mouth information regarding the way of describing puppet performances. Examining the experiences of children who use AD in puppet theatres was helpful in determining basic guidelines and special requirements to be met.

\section{Challenges in Plastusiowy pamiętnik (Plastuś'Diary) AD}

Written in 1931, Plastusiowy pamiętnik (Plastuś' Diary) is a children's book by Maria Kownacka. After being released in episodes in the Płomyczek children's magazine, it was published as a book in 1936. It is part of the canon of children's literature and is an obligatory reading in Grade 1 of primary school in Poland.

Plastusiowy pamiętnik tells the story of Plastuś - a little man made of plasticine by a 1st-grade-primary-school student, Tosia. The book is narrated in the 1st person, with Plastuś being the narrator who writes down in his diary all his own adventures as well as the adventures of his friends - school accessories - who live in Tosia's pencil case: the Pencil, the Pen, the Penknife, the Nib and the Eraser Myszka. Tosia is Plastuś's best friend. Apart from Plastuś' everyday adventures, the diary also relates Tosia's school and home stories, e.g. her friendship with Zosia, problems with the Teacher, fights with her brother Jacek or trouble with Witek, Tosia's classmate.

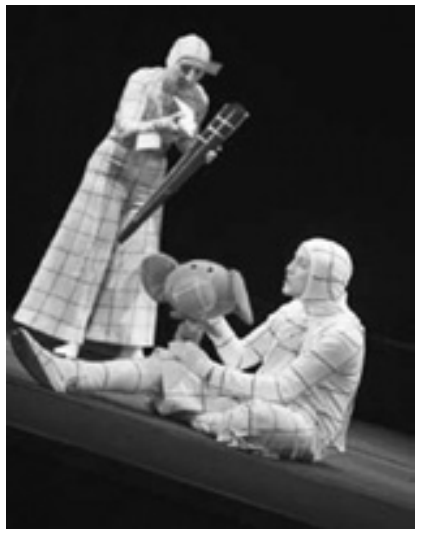

Fig. 3. The puppet of Plastuś and the personified $\mathrm{Nib}$ (phot. Albert Roca Macia)

What makes the book unusual in terms of both its interpretation and staging is the imaginary world of Tosia's pencil case. In the absence of Tosia or other human beings, Plastuś and all the school accessories live their own lives full of adventures, problems, challenges, joys and sorrows. Personified objects mimic the emotional and colourful human world. 
Plastusiowy pamiętnik had its premiere in the Baj Theatre in Warsaw on 6 December 2014. ${ }^{2}$ It was directed by Lech Chojnacki and intended for children aged 5 and older. The cast included two actresses, four actors and numerous objects. Objects and actors are mentioned in the same sentence on purpose, as the performance represented the genre of the "object theatre" (teatr przedmiotu), in which characters are played by both actors and objects that represent them. For example, in some scenes these were actors who performed the roles of school accessories, whereas in other moments actors were physically "hidden" behind them in order to emphasize the fact that these were the Eraser, Pencil or Nib who were living characters. This technique is often used to enhance the illusion of theatre as well as to make an audience believe that the objects are not only fully-fledged partners of actors, and since they do not obey the laws of physics, they are often more prominent members of the illusionary world presented on stage.

\section{Specificity of staging Plastusiowy pamiętnik in the Baj Theatre}

Due to numerous factors, such as the complex and detailed plot as well as multiplicity of characters, the text rendered itself complicated to be staged in the puppet theatre. This is why Lech Chojnacki decided that his play would not directly mimic reality. Therefore, he reduced the book's complicated plot and abundant characters to modern and minimal representation of original elements. For this reason, actors were reenacting the story on a nearly empty stage, leaving the setting to the audience's own imagination. Some locations, e.g. classroom, pencil case or Christmas tree were marked with different painted plastic boards that were lowered behind the actors. In other situations, e.g. when Plastuś was riding in a car, both the road and the car were implied and had to be visualized in the minds of the audience. Thanks to the music, sound effects, lighting and background knowledge, spectators could interpret the meaning of the scene. The changes between the scenes also had to be deduced from the context, dialogue and background knowledge.

Given that the performance represents the genre of "object theatre", it is neither dramatic nor puppet theatre. What differentiates "object theatre"

$2 \quad$ www.teatrbaj.pl. 


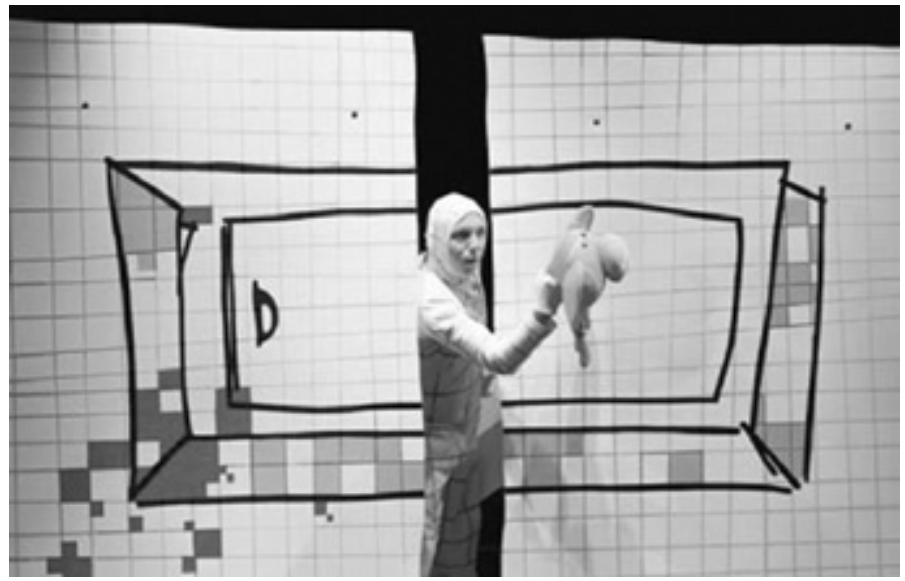

Fig. 4. A plastic board representing the pencil case (phot. Albert Roca Macia)

from dramatic theatre is that in the former protagonists are not played by actors, but by objects that represent them. In turn, the major difference between "object" and puppet theatre lies in the fact that puppets are mobile, i.e. their heads, legs, arms, bodies can be manipulated, whereas objects constitute just one block, without any limbs or mobile elements. As a consequence of this staging strategy, all the characters, i.e. Plastuś, the Pencil, the Pen, the Penknife, the Nib as well as Zosia, Tosia, Pani, Jacek and Witek were represented by objects. Plastuś was an orange, teddy-bear-like figure with a big head, huge ears and a nose. School accessories were human-sized, made of carton, painted white with some colourful details, and their size was comparable to the height of actors who were manipulating them. Human characters were represented by carton boards with holes representing shapes of faces. They resembled giant puzzles or figures with holes, so that actors' heads could be put inside them. Examples of such figures can be encountered in some museums - visitors can put their faces into the contour of the head of somebody famous and pretend they are someone else. The included pictures illustrate the artistic vision of the play's stage designer. Interestingly, the Diary was the only character that was represented by an actor and not by an object. This procedure was implemented in order to stress the fact 


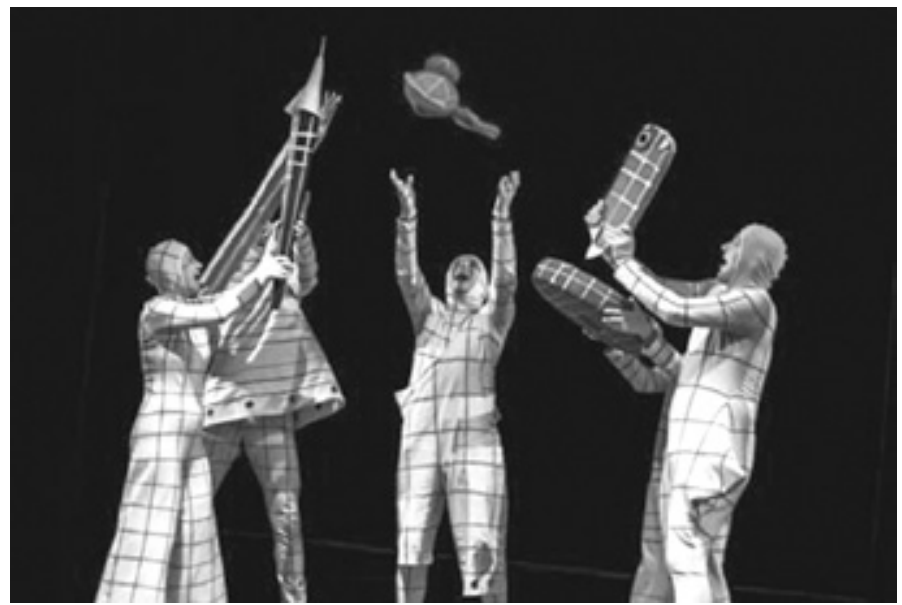

Fig. 5. Object theatre - actors manipulating personified objects (phot. Albert Roca Macia)

that the Diary was the main protagonist of the performance.

Another issue related to the staging of Plastusiowy pamiętnik in the Baj Theatre was the fact that the actors had to create many roles and deal with many tasks during the play. The same actors were representing different characters and things at different moments during the performance. Sometimes they were narrators who were introducing the audience into new scenes; they were turning into school accessories or sheets of paper from the diary; they were Tosia and her classmates at school; they were enacting obstacles (using the objects) that were impeding Plastuś's ride in his car; finally they were fulfilling

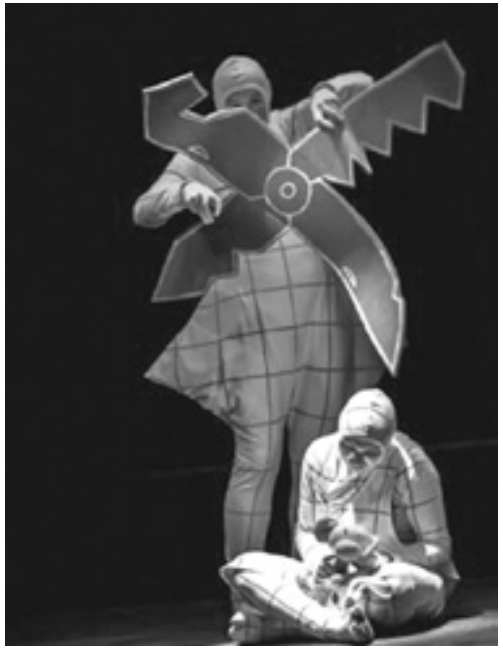

Fig. 6. The Big Penknife from Plastuś' dream - variety of dimensions of objects in the object theatre (phot. Albert Roca Macia) 
the role of technicians who were building new objects (e.g. a birthday gift for Tosia) out of separate elements found on the stage.

The scenes in the performance might be divided into two types: the standard scenes with the participation of Plastuś and school accessories only and the mixed ones where human characters (Tosia, Zosia, the Teacher, etc.) were mixed with personified objects. Given that puppet theatre "strongly relies on inference by the audience because the relation between a sign and its meaning can be very implicit at times" [ADLAB, 2014], the creative team decided to introduce two dimensions of Plastuś and school accessories so that the audience could clearly understand that personified objects are smaller than human characters. In the scenes with personified objects, only bigger objects were used. In the mixed scenes, smaller versions of personified objects were utilized in order to manifest the fact that humans are bigger than school objects and toys used by Tosia. Unlike dramatic theatre, puppet theatre is forced to introduce two sizes of objects or puppets in order to avoid confusion and create concepts of reality in the audience. This can be a challenging part of writing an $\mathrm{AD}$ script.

\section{Challenges of audio describing Plastusiowy pamiętnik}

Plastusiowy pamiętnik turned out to be a very challenging performance to audio describe. First and foremost, as previously mentioned, objects can only be moved up, down, right, left, and diagonally. Therefore, the interpretation of their intentions and behaviour depends to a great extent on the interpretation of the actors' movement, face expression, behaviour and rhythm. In some situations, objects were protagonists with actors being only their manipulators. In others, actors were taking the lead and using objects as props without "giving them life". Such changes of functions of objects turned out to be very confusing as far as writing a clear and understandable audio description is concerned. Bearing in mind the major guidelines concerning the preparation of $\mathrm{AD}$ for theatre, it was crucial not to break the suspension of disbelief by describing what actors are doing, how they are holding the objects, etc. Sighted young viewers perceive actors and objects representing them as a unity, and so should the visually impaired audience. The script author could not deprive the public with low vision of the real theatre experience. 
In dramatic theatre, such a problem would not exist due to the fact that Plastuś and other characters would be played by actors and not objects. As a consequence, audio describer in dramatic theatre would not have to struggle with the challenge of not breaking the illusion of theatre.

Other problems related to audio describing Plastusiowy pamiętnik mainly originated from the rich soundtrack, abundant songs, loud music and extremely tight time constraints - short silent moments were available in between the dialogues for the $\mathrm{AD}$ to be inserted. In order to convey all the essential information necessary for the visually impaired children to follow the plot, certain decisions, such as writing an audio introduction, had to be taken.

Another important issue was the concept of the performance. As the stage design was reduced to an absolute minimum, most of the topics, actions, items and sceneries mentioned above had to be imagined by the sighted audience and in the case of the visually impaired audience - they had to be described to them. Moreover, scarce elements that were placed on stage played a symbolic role.

Multiple acting tasks given to each actor also had to be transmitted in the AD script. As AD theatre guidelines say, it is of extreme importance not to deprive the audience of the suspension of disbelief. Consequently, descriptions like "now the actor who was a Sheet of paper takes a Pen and turns into it" were inappropriate. Another solution had to be invented. Multiple acting tasks may create confusion in visually impaired audiences for another reason. In the classroom scene, Tosia and Zosia were performed by two male actors who were also enacting Plastuś' and Diary's, Brush's or Copybook's role in other moments of the spectacle. As viewers with low vision interpret audio-visual events by recognizing the voices, they might find it surprising and confusing that Tosia not only had a male voice, but also this voice pertained to Plastuś in other scenes. It was essential to give some explanation of this phenomenon in AD.

Interestingly, another question that emerged during the preparation of the AD script was not related with technical staging issues, but stemmed from the fact that the text is quite old. As the book was written almost eighty years ago, some objects, characters and facts are not only obsolete, but also incomprehensible to the present seven-years-olds, e.g. the meaning and the function of the nib, the old Asian tradition of writing in a copy book using a brush, sharpening pencils with penknives and 
not pencil sharpeners as it is done today, or writing with ink. These details also had to be included in the AI script so that the young spectators could follow the plot from the very beginning of the play without asking their caretakers for the meaning of crucial words.

\section{Solutions: audio introduction, touch-tour, tailor-made AD}

Due to the fact that the study conducted with the purpose of examining the $\mathrm{AD}$ reception in puppet theatres was carried out in the Baj Theatre in Warsaw, the author of both this article and the AD script as well as the voice talent who delivered the $\mathrm{AD}$ is the same person: an actress and puppeteer working in the Baj theatre in Warsaw.

In view of the numerous challenges concerning audio describing Plastusiowy pamiętnik, we reached for techniques such as audio introduction (AI), customized (resembling a fairy tale) audio description, and a touch-tour prior to the performance in order to create an enjoyable and comprehensible theatre experience. The objective of choosing these strategies was to transmit the technical information and description as well as staging procedures and specificities in AI, then make visually impaired viewers discover the described props and objects during a touch-tour, and finally, relate in AD the illusionary world that was being created by actors on stage. The aim of the AD script was to resemble a fairy tale rather than an objective account of subsequent actions on the stage.

First and foremost, the audience was presented with an audio introduction text. Sitting in front of the audience and narrating the AI text, the AD author introduced the children to the play, making sure they understood everything that was being said to them by asking additional questions on AI. Audio introduction included the following information: the title of the performance, historical background and explanation of the archaic school characteristics, a detailed description of the costumes, props, items and materials they were made from, the appearance and usage of the human-like frames (puzzles) and objects, to explain the duality of every object (personified object versus a prop). Furthermore, the viewers were informed about numerous tasks that actors were engaged in as well as how objects would become alive thanks to the manipulation of actors and how actors were becoming the object which they were 
handling or manipulating in a certain moment. In such a way all the challenges described above (including complex staging strategies, extreme time constraints, conceptuality of the performance, multiple tasks of actors and specific design of objects) were overcome. Finally, it was announced that there would be an intermission during the play and after the performance children would be interviewed about the spectacle.

Reading the AI script was complemented with an immediate touchtour so that young spectators had a chance to strengthen the auditory information by tactile stimuli. Among numerous objects and forms pertaining to the play, children were given the following: Plastuś, the Eraser Myszka, Pencil, Pen, Penknife, Nib, Tosia, Zosia and Ink Blot. School accessories were presented to them in two dimensions. While children were seated, each item was given to them so that they had some time to discover and examine its shape, weight, structure, texture, fabric, etc. with their own hands. Children were passing every object and prop to each other. During the touch-tour a stage assistant and the teachers also helped explain to the children what the objects were and what they were used for. AI reading and the touch-tour were organized in the absence of the sighted audience. Children reacted in a very enthusiastic way to the possibility of getting to know the protagonists of the play they were about to see.

The third element leading to the creation of a coherent theatrical experience was writing an $\mathrm{AD}$ script tailored for young, visually impaired children with either partial or complete sight loss. During the preparation of the $\mathrm{AI}$ and $\mathrm{AD}$ script, the author took into consideration the following factors: the children's age, degree of visual memory (basing on the schools' profile) and the previous knowledge of the book (this information was provided by teachers from Educational Centre for Blind Children in Laski). Subsequently, bearing in mind that all the sounds and prolonged moments of silence and whispering build up tension and create suspense in the performance, the author respected the golden rule of no overlapping dialogues and sound effects by keeping sentences simple and as short as possible. No subordinate clauses were introduced into the script. However, due to time constraints, during several occasions the author decided to speak on top of songs and music in order to deliver essential information. The AD script provided information not only on what was happening visually, but also on the feelings of the 


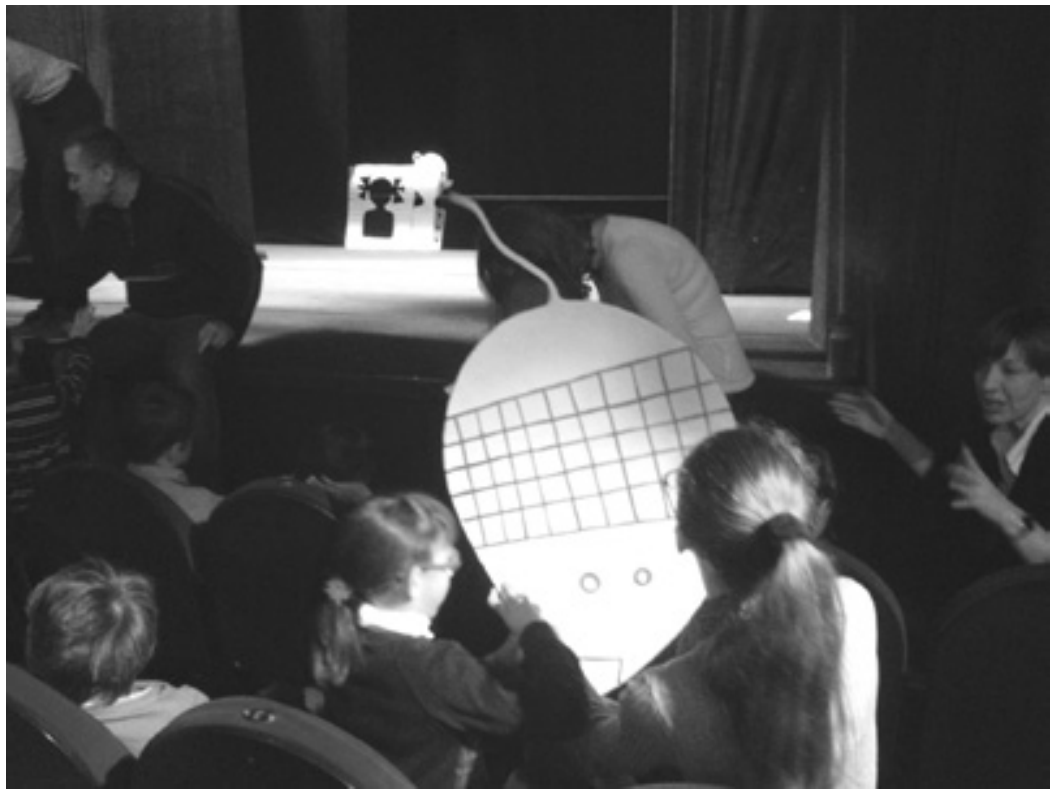

Fig. 7. Touch tour - Plastuś (phot. Agnieszka Szarkowska)

characters by interpreting their behaviour, intentions and emotions instead of describing them with objectivity. The global strategy assumed by the author consisted in domesticating the performance. To achieve this goal, the explicitation and generalization techniques were chosen. On her part, the audio describer was adjusting the tone and colour of her voice to every scene as well as changing the rhythm and pitch of the speech, in this way enhancing emotions that were created on stage. Her aim was to create an illusion of radio drama. Thanks to this procedure, children were listening to a sort of fairy tale, a story told especially for them, and not a literal account of what was seen on the stage.

\section{Conclusion}

The overall result of the study showed a very positive response to the introduction of a tailor-made and orally delivered AI, a touch-tour prior to the play, and a customized AD. The customization of these three 
elements consisted in preparing a narrative, fairy-tale like AD script that lacked objective and emotionless descriptions; separating technical information (included in AI script) from illusionary descriptions (given in AD script); as well as facilitating a touch-tour aimed to discover puppets and objects present in the play. The performance was greeted with both warm welcome and signs of satisfaction and enjoyment expressed by the faces in the audience. It could be observed that the young spectators were grateful for the unique experience of watching the play and participating in the touch-tour designed especially for them. Even though there is plenty of space for improvement as far as both the organization of a visit to a puppet theatre for the blind and preparation of an AD script are concerned, a new path has been marked. It is hoped that these findings will contribute to provide a visually-impaired young audience with access to theatre performances designed especially for them.

\section{References}

ADC (2006), The Audio Description Coalition Standards for Audio Description and Code of Professional Conduct for Describers, [on-line] www.audiodescriptioncoalition.org/standards.html - 10.12.2015.

ADI (2002), Audio Description International, Guidelines for audio description, [on-line] www.acb.org/adp/guidelines.html - 10.12.2015.

ADLAB (2014), Audio Description: Lifelong Access for the Blind, [on-line] www.adlabproject.eu/Docs/adlab\%20book/ - 10.12.2015.

AENOR (2005), Audiodescripción para personas con discapacidad visual. Requisitos para la audiodescripción y elaboración de audioguías, [on-line] www.aenor.es/aenor/normas/ctn/fichactn.asp?codigonorm=AEN/CTN\%20 153\&pagina=1\#.VNzXuyy9F9k - 10.12.2015.

Braun, S. (2008), the final draft of an article published as: "Audio Description Research: State of the Art and Beyond", Translation Studies in the New Millennium, 6, pp. 14-30.

Calderazzo, D. (2010), “The 'Stage in the Head': A Cognitive Approach to Understanding Audio Description in the Theatre", Theatre Topics, XX, 2, pp. 171-180.

Chmiel, A., Mazur, I. (2011) “Audiodeskrypcja jako intersemiotyczny przekład audiowizualny - percepcja produktu i ocena jakości”, in: Kasperska, I., 
Żuchelkowska, A. (ed.) Przektad jako produkt i kontekst jego odbioru, Rys, Poznań, pp. 13-30.

Díaz Cintas, J. (2005), “Audiovisual Translation Today. A Question of Accessibility for All", Translating Today Magazine, 4, pp. 3-5.

Holland, A. (2009), "Audio Description in the Theatre and Visual Arts: Images into Words", in: Díaz Cintas, J., Anderman, G. (eds), Audiovisual Translation. Language Transfer on Screen, Palgrave Macmillan, Basingstoke, pp. 170-185.

ITC (2000), Guidance On Standards for Audio Description, [on-line] www.itc. org.uk - 10.12.2015.

Jakobson, R. (2000 [1959]), “On linguistic aspects of translation”, in: L. Venuti (ed.), The Translation Studies Reader, Routledge, London-New York, pp. 113-118.

Jurkowski, H. (1983), “Transcodification of the Sign Systems of Puppetry”, Semiotica, XLVII, 1-4, pp. 123-146.

Künstler, I. (2014), “Cel uświęca środki audiodeskrypcji”, Przekładaniec, 28, pp. 48-62.

McPharlin, P. (1938), in: Tillis, S. (1992), Towards an Aesthetics of the Puppet, Greenwood Press, Westport CT, p. 47.

Morisset, L., Gonant, F. (2008), L'audiodescription Principes et Orientations, [on-line] www.csa.fr/Espace-juridique/Chartes/Charte-de-l-audiodescription-Decembre-2008 - 10.12.2015.

Ofcom (2008), Code on Television Access Services, www.ofcom.org.uk/tv/ifi/ codes/ctas/ctas.pdf - 10.12.2015.

Orero, P. (2011), "Audio description for children: Once upon a time there was a different audio description for characters", in: Di Giovanni, E. (ed.), Entre texto y receptor: Accesibilidad, doblaje y traducción [Between text and audience: Accessibility, dubbing and translation], Peter Lang, Frankfurt, pp. 169-184.

Palomo López, A. (2008a), "Audio Description as Language Development and Language Learning for Blind and Visual Impaired Children”, in: Hyde Parker, R., Guadarrama Garcia, K. (eds), Thinking Translation: Perspectives from Within and Without, BrownWalker Press, Boca Raton, pp. 113-127.

Palomo López, A. (2008b), "Writing an Audio Description Script for a Children's Film", in: Translation: Theory and Practice Postgraduate Translation Symposium, University of East Anglia, Norwich, PP presentation. 
Reason, M. (2008), “'Did You Watch the Man or Did You Watch the Goose?' Children's Responses to Puppets in Live Theatre", New Theatre Quarterly, 24, 4, pp. 337-354.

Szarkowska, A. (2008), "Przekład audiowizualny w Polsce - perspektywy i wyzwania", Przektadaniec, 20, pp. 8-25.

Szarkowska, A., Jankowska A. (2016), "Strategie opisu kulturemów w audiodeskrypcji”, Między Oryginałem a Przektadem, 31, pp. 137-152.

Szarkowska, A., Künstler, I. (2012), “Audiodeskrypcja w kinie, teatrze I muzeum: wprowadzenie do działań praktycznych", in: Trzeciakiewicz, M. (ed.) Audiodeskrypcja w teorii i praktyce, czyli jak mówić o tym, czego nie można zobaczyć, Fundacja Katarynka, Wrocław, pp. 65-107.

Szymańska, B., Strzymiński, T. (2010), Obraz stowem malowany. Standardy tworzenia audiodeskrypcji do produkcji audiowizualnych, [on-line] www. audiodeskrypcja.org.pl. - 10.12.2015.

\section{Summary}

The aim of this paper is to review existing guidelines and strategies for $\mathrm{AD}$ in children's theatre and to prepare an accessible visit for visuallyimpaired children to a puppet theatre. Taking under consideration the complexity of Plastusiowy pamiętnik (Plastuś' Diary) the performance chosen to be audio described, we decided to create an audio introduction, AD script and a touch-tour prior to the spectacle. We believed that in such a way children could enjoy the play to the same extent as the sighted audience do. Our intention was to find out how to describe the convention of puppet theatre as well as to reach the balance between the abundance of stimuli in the play and information that should be delivered in the AD script, without breaking the suspension of disbelief.

Key words: audiovisual translation, audio description, accessibility, puppet theatre for children, audio introduction

\section{STRESZCZENIE}

Audiodeskrypcja w teatrze lalek dla dzieci - studium przypadku Niniejszy artykuł poświęcony jest tematyce tworzenia audiodeskrypcji (AD) do spektakli lalkowych dla dzieci. W tym celu została 
przygotowana audiodeskrypcja do spektaklu Plastusiowy pamiętnik Marii Kownackiej w reżyserii Lecha Chojnackiego w warszawskim Teatrze Baj oraz zostało zbadane, jak tekst audiodeskrypcji pomógł najmłodszym widzom $\mathrm{z}$ dysfunkcją wzroku $\mathrm{w}$ odbiorze spektaklu. Analiza wyników badania przeprowadzonego po obejrzeniu spektaklu dostarczyła informacji, jak powinien brzmieć tekst AD do spektakli lalkowych dla najmłodszych oraz czy dodatkowe udogodnienia, takie jak wprowadzenie do spektaklu czytane na żywo lub oprowadzenie po scenie z możliwością dotknięcia lalek, rekwizytów i kostiumów aktorów, pomagają niewidomym dzieciom w pełni uczestniczyć w spektaklu teatralnym z obecnością lalek.

Słowa kluczowe: tłumaczenie audiowizualne, audiodeskrypcja, dostępność, teatr lalek dla dzieci, audiowstęp 